A National Health Service? 
Also by John Mohan

The Political Geography of Contemporary Britain (editor) 


\section{A National Health Service?}

The Restructuring of Health Care in Britain since 1979

John Mohan

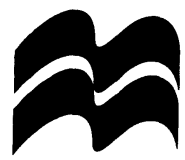


All rights reserved. No reproduction, copy or transmission of this publication may be made without written permission.

No paragraph of this publication may be reproduced, copied or transmitted save with written permission or in accordance with the provisions of the Copyright, Designs and Patents Act 1988, or under the terms of any licence permitting limited copying issued by the Copyright Licensing Agency, 90 Tottenham Court Road, London W1P 9HE.

Any person who does any unauthorised act in relation to this publication may be liable to criminal prosecution and civil claims for damages.

First published in Great Britain 1995 by

MACMILLAN PRESS LTD

Houndmills, Basingstoke, Hampshire RG21 2XS

and London

Companies and representatives

throughout the world

A catalogue record for this book is available

from the British Library.

ISBN 978-0-333-57832-2 ISBN 978-1-349-23897-2 (eBook)

DOI 10.1007/978-1-349-23897-2

$\begin{array}{llllllll}10 & 9 & 8 & 7 & 6 & 5 & 4 & 3\end{array}$

$\begin{array}{lllllllll}04 & 03 & 02 & 01 & 00 & 99 & 98 & 97 & 96\end{array}$

First published in the United States of America 1995 by

Scholarly and Reference Division,

ST. MARTIN'S PRESS, INC.,

175 Fifth Avenue,

New York, N.Y. 10010

ISBN 978-0-312-12410-6 (cloth)

Library of Congress Cataloging-in-Publication Data

Mohan, John, 1958-

A National Health Service? : the restructuring of health care in Britain since 1979/John Mohan.

p. $\mathrm{cm}$.

Includes bibliographical references and index.

ISBN 978-0-312-12410-6 (cloth)

1. National Health Service (Great Britain) 2. Medical policy-Great Britain. I. Title.

RA395.G6M64 1995

$362.1^{\prime} 0941-\mathrm{dc} 20$ 


\section{Contents}

List of Tables and Figures

viii

Preface

$\mathrm{X}$

List of Abbreviations

xix

1 From the Royal Commission to the NHS Reforms: A Review of Policies and Statistics

Key policy developments and changes 3

Inputs: trends in health care finance 9

Provision: beds, staffing and activity 17

Outcomes? $\quad 22$

Concluding comments 23

2 Explaining Change in the Welfare State and in Health Care Policy

Developmentalism and determinism 26

Political theory: pluralism, Marxism and the New Right

Political economy: crises, restructuring, disorganised capitalism and post-Fordism

Concluding comments

3 Conservatism, Health Policy and Health Care Policy 44

Thatcherism, conservatism and health care policy 46

Redefining the scope of health policy 48

Setting a new agenda for health care $\quad 54$

A change of pace, not of direction? 65

$\begin{array}{ll}\text { Concluding comments } & 70\end{array}$

4 Spatial Resource Allocation: Local Difficulties, Technical Adjustments and Political Solutions

RAWP under austerity: from differential growth to equality of misery?

A national crisis or a little local difficulty? $\quad 84$ 
Technical solutions: from RAWP to weighted capitation

Planning versus the market: Tomlinson and beyond

Concluding comments

5 Imagined and Imaginary Communities: Rhetoric and Reality in Community Care Policy

The ideological appropriation of community 103

Needs, expenditure and services

The development of community care policies: themes and assumptions

Implementing community care: incompetence or malice?

Caring for People: delays and unresolved questions

Concluding comments

6 Producing Health Care: Management, Labour and the State in the NHS

Aggregate trends in the NHS workforce

The 'core': medical staff and the recasting of administrators as managers

The 'periphery': Whitley Council staff

Recruitment difficulties and 'geographical pay' 145

The White Paper and beyond

Concluding comments

7 Blurring the Boundaries: Health Care Outside the NHS

Historical background: state policies and private sector growth

Dynamics of change in the commercial sector

Government-industry relations and the effects of the NHS reforms

Wider implications

8 The Entrepreneurial State: Commercial and Charitable Activities by Health Authorities

Back to the future? Charitable fundraising and charitable trusts

The entrepreneurial welfare state: commercialisation of health authority activity 
Self-governing trusts, GP fundholding and the postWhite Paper organisation of the NHS

Concluding comments

9 Powers, Responsibilities and Accountability:

Organisational Reform and Local Autonomy

Organisational reforms

Centre versus periphery

Beyond the reforms?

Concluding comments

10 Conclusions: In What Sense a National Health Service?

Geography, locality and welfare

Markets, planning and ethics

Boundary disputes

Alternatives

Appendix: Chronology of Major Developments in Health and Health Care Policy since 1979

Notes and References

Bibliography

Index 


\section{List of Tables and Figures}

\section{Tables}

1.1 Trends in actual and planned expenditure on the HCHS in England, 1982-3 to 1993-4

1.2 Sources of savings from cost improvement programmes, $1985-6$ to $1990-1$

4.1 RHAs' distance from revenue targets, long-term revenue growth assumptions and financial increments, 1983-91

4.2 Trends in actual current expenditure on the HCHS, English RHAs, 1983-7

6.1 Change in NHS staffing by main staff groups, 1981-91 134

6.2 Vacancy rates for qualified nursing staff by region, 1989-92

7.1 Private medical insurance coverage, 1982 and 1987

7.2 Contribution of the private sector to elective surgery, 1981 and 1986

\section{Figures}

4.1 RHAs in England, 1974-94

4.2 Regions' distance from RAWP revenue targets, 1979-80 to $1988-9$

4.3 Percentage change in DHA acute beds, England, 1979-89

4.4 Surveys of the financial position of health authorities in England, 1987-8 and 1988-9

4.5 English DHAs: percentage change in budgets if white paper system in operation

5.1 Per capita net expenditure on personal social services, England, 1990-1

5.2 Balance of residential care for the elderly, England,1980-1 to $1990-1$

5.3 Provision for persons with mental illness, England, 1983-92 
5.4 Residential provision for persons with learning difficulties, England, 1974-92

7.1 Distribution of acute hospitals in the private sector, 1992

9.1 Areas to be covered by proposed regional units of the NHS Management Executive 


\section{Preface}

This book grew out of a project that attempted to document some of the regional and local consequences of changes in the NHS under successive Conservative governments since Margaret Thatcher was first elected Prime Minister in 1979. In the course of that project, and certainly once the NHS reforms were enacted, it became clear that a significant question was whether the reforms represented a radical departure for the NHS, or whether they were a natural outgrowth of existing trends. Kenneth Clarke put this succinctly when introducing Working for Patients (Secretary of State for Health, 1989a) in parliament: he suggested that the reforms represented a 'change of pace, not of direction'. Certainly it is possible to identify many antecedents of the reforms in the policies pursued since 1979, but this is not to suggest that the Conservatives had in mind a blueprint that has been implemented in an unproblematic fashion. It therefore seemed important to investigate the road the Conservatives had taken (as well as the roads not taken), the pace at which they had travelled along that road and the causes of changes in pace. To continue the navigational metaphor, the government's course was not always straight through a succession of green lights. It involved a certain amount of stargazing and trusting to the compass, it required decisions to be taken at junctions, and very occasionally a potential route was blocked. The journey was not trouble free nor was it an inevitable progression (though some have represented it as such - see Chapter 2).

One could spend a substantial time tracing the roots of present policies, but I argue - following in some respects Davies (1987) - that various consistent strands of policy can be traced at least to 1979 . Among these are the following:

- The stress on the finite public purse, evoked consistently as justification for both limiting the resources available to the NHS and for introducing new methods of work organisation and management reforms.

- The importance placed on management - in the Thatcher and Major years considerable emphasis has been placed on the need for firm and efficient management in the public sector, and this legacy, even 
more than specific policy changes, will far outlive their respective administrations.

- The importance attached to the private health sector as a potential competitor to the NHS, as a model for innovation that the NHS should strive to emulate, as a desirable supplement to the state's limited resources, and as a useful resource for local managers. While no post war government has attempted to eliminate private health care or private practice, with the exception of Labour's limited attack on paybeds from 1976, no government has attached such importance to the private sector.

- The encouragement of individual and community initiative and the placing of more of the burden of health care provision and financing on individuals, families and 'communities'. Much of this has been in the form of ideological statements rather than direct legislative measures, but there have been measures aimed at deregulating the commercial sector and at expanding state support for private health care. In addition, prevention of ill-health has been defined largely as a matter of individual choice and lifestyle.

- An apparent stress on localism and autonomy. The government has emphasised its wish to decentralise decision making to the lowest possible level, but in its desire to pursue certain national policies it has regularly contradicted this: in practice there has often been greater central control over local tiers of administration.

Based around these five points, changes in the British health sector are seen not in terms of a technological determinism (an interpretation that would stress the increased capacity, complexity and sophistication of the health care system); nor in terms of assumed parallels between the NHS and other complex organisations (and thus assuming that the kind of organisational reforms that have taken place were natural trends, common to any complex public or private body confronted with growing demands on and expectations of its services), nor even in terms of a supposed 'convergence' in the welfare systems of advanced capitalist states (that is to say, advocating greater spending on private health care because all similar states are going in the same direction). There is more than a grain of truth in all these arguments, but the fact remains that the responses to these economic and technical changes involved particular political choices at particular times. This raises the question of whether such responses were really necessary or whether alternatives could have been pursued.

The primary explanatory focus in this book is on the political economy of conservatism: the responses to the trends concerned were 
and are essentially political decisions. Their satisfactory understanding therefore requires analysis of the political circumstances and constraints under which they came about, their relationship to notions of 'Thatcherism' (and, to the extent that it can be distinguished from Thatcherism, 'Majorism') as a political force, and the particular strategies pursued by successive Conservative administrations. In this context I would argue, contra Klein (1984a; 1989), that it is not the case that the 'reality of politics' has forced a 'retreat from ideology' as far as Conservative health care policies are concerned; nor was there anything 'inevitable' about the 1989 NHS White Paper. Whereas the government's case for the White Paper was based on the persistence of local variability in the costs of NHS activities and throughput, and not on the absence of resources, in practice the problems of the NHS were rather more than local difficulties (Chapter 4). The White Paper was also characterised by many of the hallmarks of the policy-making style of the Thatcher administrations, a style that strongly reflected the populist instincts of the party and the then Prime Minister. Partly as a result, it did not address the real causes of inequalities in health; it merely proposed limited internal reforms within the NHS itself, as opposed to radical alterations to the nature of health care delivery. To link the White Paper to a well-known theme in political science, it was arguably about the symbolic use of politics to address - or rather to present the appearance of addressing - intractable problems (cf. Edelman, 1971) and advance a particular agenda. It was a partial and selective approach to the problems of health care delivery.

\section{Geography, politics and health care}

One theme running through this book, then, is changes in health care delivery in relation to perspectives on contemporary conservatism and the political economy of the welfare state. A second theme (without resorting to disciplinary imperialism) is the important effect that space and spatial relationships, and their interrelations with political change, have had on developments in the NHS. In a simple sense this is a matter of uneven development: the differential impact of the changes described had consequences not just for the availability of services at the time, but for their future development as communities become more dependent on resources generated or available locally. These matters are especially important given the growing significance of 
private sources of health care (Chapters 5 and 7): there may be, to paraphrase Titmuss, an emerging spatial division of welfare.

Secondly, matters of spatial distribution become questions of territorially-based conflict. Even in an ostensibly 'national' health care system there exist spatial coalitions that have greater or lesser degrees of cohesion and homogeneity, and that articulate claims on behalf of particular places. Thus many of the debates around the RAWP formula can be linked to the contentions of backbench MPs from the Home Counties about the relative pace with which services were being developed in London and the South East (Chapter 4). The London lobby, campaigning for the preservation or development of the capital's health care services, is also a key spatial coalition.

Thirdly, some interpretations of Conservative political strategies suggest that since 1979 we have seen the departure of the 'one-nation' politics of the postwar settlement and its replacement by a 'two-nation' politics of inequality (Chapter 3). This spatial metaphor sees the 'first nation' having priority over the 'second nation', with strategies being developed to maximise the electoral support given to the Conservatives from their geographical and social heartlands. The value of this interpretation is explored in Chapters 4, 7 and 8.

Fourthly, the question arises as to whether problems with health care delivery are merely 'local' difficulties, as government ministers have often suggested, or more generalised problems affecting the whole of the service. This has been the subject of considerable debate and it influences the defining of problems and their political solution. Thus the 'crisis' in the NHS in the winter of 1987-8 was initially dismissed as the problem of a few DHAs only, while staff shortages in the mid-1980s were likewise claimed to reflect labour market problems in a few highcost locations (Chapter 6). This has had political ramifications in terms of potential solutions.

Fifthly, in the light of current debates about citizenship and the rights and responsibilities thereof, one effect of post-1979 policies, perhaps as never before in the postwar period, has been that the services available have come to depend increasingly on the balance between public and private, statutory and community services in any one locality. But was it ever the intention that such capricious influences as the relative cost of nursing-home care in different regions of the country should determine access to long-stay care within the benefit limits imposed by the government? And was it intended that the internal market would deprive residents of certain localities of access to non-urgent procedures, depending on the resources available to and/or 
the whims of their health authority? The rights of citizenship appear to be geographically differentiated.

Finally, a consistent theme running through debates on the service since 1979 has been the appropriate balance of power between centre and locality (Chapter 9). The changing territorial organisation of the service is one obvious consequence of these debates, as is the extent of local autonomy accorded to health authorities and management units. This raises the question of the extent or otherwise of local control over health services.

\section{Outline of the book}

This book is organised as follows. Chapter 1 presents an outline of key policy changes and a statistical review of trends in finance, provision and activity. In Chapter 2 I consider some of the interpretations that might be advanced to explain changes in the character of public service delivery in recent years. The chapter first criticises, as oversimplistic, analyses of developments in welfare states that merely postulate evolutionary trends or rely on narrowly determinist arguments for their explanations. It then considers analyses of the political economy of welfare that relate developments in the welfare state to the apparently contradictory position of state-provided welfare systems: rather than being determined by the so-called crisis of the welfare state, the responses to changed economic circumstances are a contingent matter. Hence analyses need to be pitched at a lower level of abstraction, focusing on the specifics of political developments within individual nation-states. In this context a focus on the political economy of contemporary conservatism is crucial. Consequently Chapter 3 is devoted to an analysis of the various interpretations of Thatcherism and the implications of Thatcherite political strategies for health care policy-making and implementation.

Some of the most dramatic effects of health care policies since 1979 can be seen through an analysis of the political geography of resource allocation within the NHS (Chapter 4). There is, first of all, debate over the pace of resource redistribution between regional health authority areas. Secondly, the regional and subregional consequences of resource redistribution are described, using not only statistics on hospital bed provision and finance, but also survey data produced by the National Association of Health Authorities on the financial situation of district health authorities, and the comments of numerous backbench MPs 
about the impacts of health care policies on their constituencies. The geographical impacts of the reforms, and of the Tomlinson Report, are also given attention.

As well as the spatial distribution of resources, the sectoral distribution of resources must also be analysed. Community care for the mentally ill and the elderly is an area where policy has persistently failed to match rhetoric. Chapter 5 examines the changes introduced since 1979 to determine how far they represented a break with previous practice and how far they reflected the ideological predilections of the government. It concentrates particularly on community care for the mentally ill and those with learning difficulties, and on care for the elderly, and asks how far there is a commitment to national standards and to a national service.

In an essentially labour-intensive service such as the NHS, continued attention to labour costs is essential if greater levels of productivity are to be achieved within existing resources. Precisely what measures are taken with this in mind is a matter for political decision, as will be shown in chapter 6 with respect to certain key measures taken since 1979. Equally, for policy innovations to work, the support of certain key workers within the NHS needs to be guaranteed. There has been an element of selectivity about the policies pursued: on the one hand they have prioritised the interests of key workers such as NHS 'managers' and, on the other hand, have marginalised other groups, notably ancillary workers. Consideration is given to the value of the distinction advanced by some commentators between 'core' and 'peripheral' workers.

Chapter 7 explores the development of the private, or more accurately the commercial health sector since 1979, focusing on the internationalisation and commercialisation of health care. The continued growth of commercial health care can only partly be explained by consumerist forces, because state policies have had the intended and unintended effect of expanding commercial health care. Related to this latter point, a number of measures have been deliberately taken to expand the actual and potential role of nonstate sources of funds and health care provision, and the actual and likely impacts of these are reviewed in Chapter 8 . These two chapters provide an opportunity to consider the various meanings of and explanations attached to notions of 'privatisation'. They also raise the question of whether developments in the 1980s have marked a decisive shift away from a health care service in which the producing and financing of services were de facto monopolies of the state, and whether a 'mixed economy' of services will henceforward be the norm. 
No analysis of the political economy of the British health sector would be complete without consideration of the changing balance between central and local tiers of administration in the political process (Chapter 9). The NHS has always been caught between centre and locality, a situation that is hardly surprising given that service providers are accountable both to their local communities, who experience the consequences of their decisions, and to the secretary of state for health, who is ultimately responsible for financial control. Balancing these two accountabilities is a task that will continue to tax politicians, health professionals and authority members. Chapter 9 considers not only the changing spatial organisation of the NHS, but also the apparent decentralisation of authority and the extent to which this is contradicted by the government's determination to impose its authority on local tiers. Finally the effects of the white paper on the territorial organisation of services are examined.

In the concluding chapter some wider issues that will affect the future of health care provision are discussed. These include questions of ethics, in terms of appropriate management of public services, rights, in terms of access to care, and the entitlements and responsibilities of citizenship. In addition, the question of the boundaries between state, market and community provision is discussed, and the question is raised of whether there still exists a truly national health service.

This book is not a complete chronology of events since 1979; instead it concentrates on key issues that illuminate areas where the Conservatives have introduced substantial and radical changes that clearly distinguish their policies from those of their predecessors. The focus is also on the macropolitical environment rather than on the technical details of specific initiatives. Other texts are available that cover in more detail the administrative changes in the NHS (for example Ham, 1992; Harrison et al., 1990). Because of its national focus this book does not present the kind of local detail evident in, for instance, the work of Davidson (1987) or Widgery (1988). There remain to be written accounts of the ways in which the NHS reforms have worked out in specific places, and of their impacts on specific groups in the population, and these will necessarily be more qualitative and ethnographic in character. Nor does the book purport to be a formal evaluation of post-1979 changes - see Le Grand et al. (1990) or Bloor and Maynard (1993) for an assessment of funding issues, and Le Grand and Robinson (1994) for preliminary assessments of the reforms. 


\section{A note on sources}

In general this book draws heavily on sources such as Hansard and on the deliberations of government select committees, the areas in which government policy receives its most sustained examination. On occasion these sources also reveal governmental attempts to test the limits of certain strategies (the debates on the Health and Medicines Bill - Chapter 3 - and on the financing of private residential care Chapter 5 - are good examples of this). Elsewhere, as in Chapters 6 and 8 , professional journals are used extensively as the best possible source of up-to-date information on innovations within the service and on the attitude of professional groups. Where possible national statistical sources are used, but comparable data for the beginning and end of the period in question are difficult to obtain, as are subregional data due to various reorganisations of the service. For a number of technical reasons the manner in which certain statistics were collated and presented changed during this period, and the government was regularly criticised for appearing to misrepresent or suppress information in order to make its policies appear in the most favourable light (Smith, 1987; Marmot and McDowell, 1986; Radical Statistics Health Group, 1985, 1987, 1992). The book has relied largely on data published through official sources, with all the limitations that might imply. Given the pace of change in the NHS, I should also point out that the text of the book was finalised in May 1994

Given these caveats, I hope that the book will provoke debate not just about the transformations the NHS has experienced since 1979, but its possible development for the future. 


\section{Acknowledgements}

First of all I am grateful to the ESRC for financial support through a postdoctoral research fellowship (grant no. A23320036). Although the focus of that project was somewhat narrower than the present one, it nevertheless stimulated the lines of inquiry pursued here. I am also grateful to colleagues in the Geography Department, Queen Mary and Westfield College, for providing a supportive environment for my work. It would be impossible to list those who commented on earlier drafts of several chapters without running the risk of leaving some out, and simultaneously depriving the book of sympathetic reviewers, but I must mention David Smith, who first encouraged me to work at QMW and has supported my work ever since. Both David Smith and Geof Rayner commented, from rather different perspectives, on a draft of this book and I am enormously grateful to them for doing so. As ever, Steven Kennedy has been a patient and constructive commissioning editor.

I would also like to acknowledge the assistance of staff in various libraries, notably the King's Fund Centre, the LSE, the University of London, and Queen Mary and Westfield College, and the help of the technical and secretarial staff in the Geography Department, QMW, especially in the later stages of preparing the typescript. Finally, Ellie, Jennifer and Clare provided - in their different ways - constant support, diversion and disruption throughout the writing of this book.

JOHN MOHAN 


\section{List of Abbreviations}

ACHCEW Association of Community Health Councils in England and Wales

AHA Area Health Authority

AIDS Acquired immune deficiency syndrome

AIH Association of Independent Hospitals

AMI American Medical International

BMA British Medical Association

BMJ British Medical Journal

BUPA British United Provident Association

CCMA Contract Cleaning and Maintenance Association

CHC Community Health Council

CIPs Cost improvement programmes

COHSE Confederation of Health Service Employees

CPRS Central Policy Review Staff

CRESs Cash-releasing efficiency savings

DoE Department of the Environment

DoH Department of Health

DHA District Health Authority

DHSS Department of Health and Social Security

DMUs Directly Managed Units

DSS Department of Social Security

EC European Community

FCE Finished Consultant Episode

FHSA Family Health Service Authority

FPC Family Practitioner Committee

GDP Gross domestic product

GHS General Household Survey

GLC Greater London Council

GP General practitioner

GOS Great Ormond Street

HCA Hospital Corporation of America

HCHS Hospital and community health service

HEA Health Education Authority

HMOs Health maintenance organisations

HPSS Health and Personal Social Services

HSB Health Services Board 
HSJ Health Services Journal

IHA Independent Healthcare Association

IHG Independent Hospitals Group

NAHA National Association of Health Authorities

NAHAT National Association of Health Authorities and Trusts

NALGO National and Local Government Officers

NAO National Audit Office

NHS National Health Service

NHSME National Health Service Management Executive

NHSTF National Health Service Trust Federation

NUPE National Union of Public Employees

OPCS Office of Population Censuses and Surveys

PPP Private Patients Plan

PRB Pay Review Body

PRP Performance-related pay

RAWP Resource Allocation Working Party

RCN Royal College of Nursing

RHA Regional Health Authority

RHA Regional Hospital Board

RMI Resource management initiative

RPI Retail price index

SHAs Special Health Authorities

SMR Standardised mortality ratio

SWS Schumpeterian workfare state

WHO World Health Organisation

WTE Whole-time equivalent 